\title{
Uranyl peroxide nanoclusters at high-pressure - CORRIGENDUM
}

Katlyn M. Turner, Jennifer E.S. Szymanowski, Fuxiang Zhang, Yu Lin, Brendan T. McGrail, Wendy L. Mao, Peter C. Burns, and Rodney C. Ewing

doi: 10.1557/jmr.2017.301, Published by Materials Research Society with Cambridge University Press, 14 August 2017

In Turner et al. ${ }^{1}$, Fig. 1 was displayed with incorrect dimensions and was therefore distorted. The following is the correct figure:

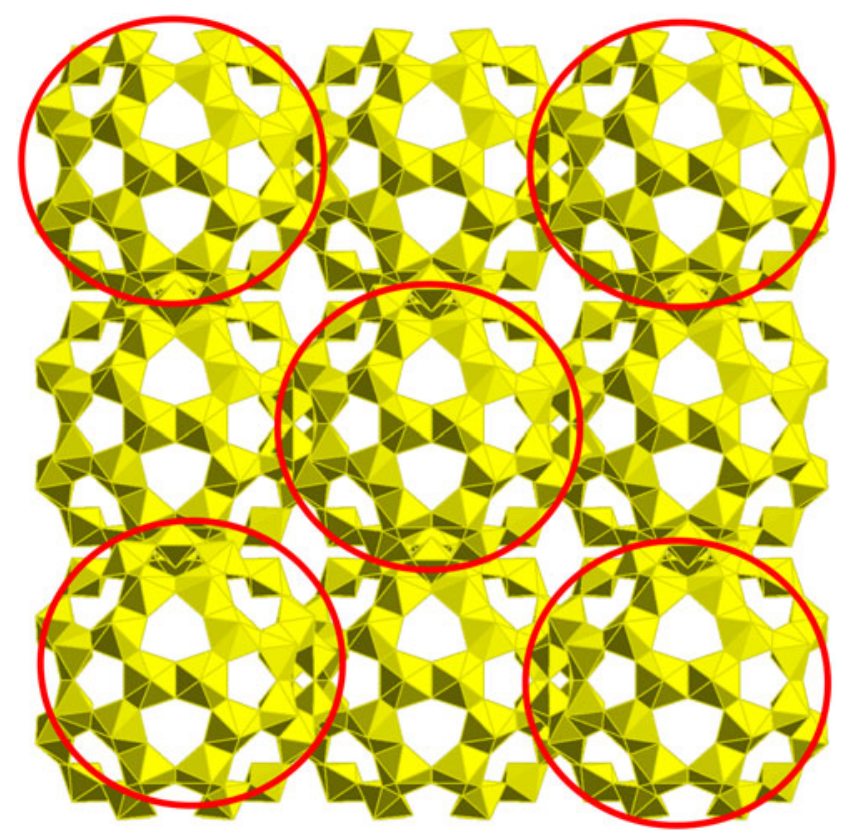

FIG. 1. One unit cell (a $537.884 \AA$, from the [100] direction) of the $\mathrm{U}_{60}$-bearing crystalline compound: $\mathrm{Li}_{68} \mathrm{~K}_{12}(\mathrm{OH})_{20}\left[\mathrm{UO}_{2}\left(\mathrm{O}_{2}\right)(\mathrm{OH})\right]_{60}$ $\left(\mathrm{H}_{2} \mathrm{O}\right)_{310}$ with $\mathrm{Li}, \mathrm{K}$, and $\mathrm{H}_{2} \mathrm{O}$ omitted for clarity. Cluster molecules circled are in-plane with the page.
The authors and publisher regret this error.

\section{REFERENCE}

1. K.M. Turner, J.E.S. Szymanowski, F. Zhang, Y. Lin, B.T. McGrail, W.L. Mao, P.C. Burns, and R.C. Ewing: Uranyl peroxide nanoclusters at high-pressure. J. Mater. Res. (2017). doi: 10.1557/ jmr.2017.301

DOI: $10.1557 /$ jmr.2017.367 